\title{
Effect of rumen-protected niacin on lipid metabolism, oxidative stress, and performance of transition dairy cows
}

\author{
K. Yuan, R. D. Shaver, ${ }^{1}$ S. J. Bertics, M. Espineira, and R. R. Grummer \\ Department of Dairy Science, University of Wisconsin-Madison, Madison 53706
}

\begin{abstract}
The objective of this study was to evaluate the effect of a rumen-protected niacin product (RPN; $65 \%$ nicotinic acid; NiaShure, Balchem Corp., New Hampton, NY) on lipid metabolism, oxidative stress, and performance of transition dairy cows. Thirty nonlactating multiparous Holstein cows in late gestation were paired according to expected calving date and randomly assigned to $12 \mathrm{~g} /$ cow per day of RPN product or to an unsupplemented control $(\mathrm{CON})$ diet. Treatment diets were fed from $21 \mathrm{~d}$ before expected calving through $21 \mathrm{~d}$ after parturition. Blood samples were taken on d $-21,-14,-7,1,7,14$, and 21 relative to calving for plasma nonesterified fatty acid (NEFA), $\beta$-hydroxybutyrate (BHBA), glucose, and superoxide dismutase (SOD) analyses. Liver samples were taken by biopsy on $\mathrm{d} 1$ and 21 relative to calving for triglyceride (TG) analysis. Data were analyzed for a randomized complete block design with repeated measures. Pre- and postpartum dry matter intake, milk yield, and protein were unaffected by treatment. Milk fat percentage (5.08 vs. $4.44 \%$ ) and somatic cell score (3.93 vs. 2.48) were reduced for RPN. Treatment $\times$ time interactions were observed for energy-corrected milk (ECM) and fat-corrected milk (FCM) yields; RPN reduced ECM and FCM yields by 8.5 and $8.9 \mathrm{~kg} /$ cow per day, respectively, in the first week of lactation. Although body weight and condition score decreased during the experimental period, no differences due to treatment were observed. However, calculated postpartum energy balance tended to be improved for RPN because of the reduction in ECM yield. Time and treatment $\times$ time effects were observed for plasma NEFA. On d 1 postpartum, NEFA reached 1,138 $\pm 80 \mu \mathrm{Eq} / \mathrm{L}$ for CON compared with $698 \pm 80 \mu \mathrm{Eq} / \mathrm{L}$ for RPN. Cows supplemented with RPN tended to have lower plasma NEFA concentrations than CON cows on $\mathrm{d} 7$ and 14 postpartum. Plasma BHBA, glucose, and SOD and liver TG concentrations were unaffected by treatment. In conclusion, supplementation with $12 \mathrm{~g} / \mathrm{cow}$
\end{abstract}

Received October 26, 2011.

Accepted January 5, 2012.

${ }^{1}$ Corresponding author: rdshaver@wisc.edu per day of the RPN product provided a bioavailable source of niacin that modified lipid metabolism but did not affect milk yield over the first 3 wk of lactation or oxidative stress of transition dairy cows.

Key words: nonesterified fatty acid, rumen-protected niacin, transition cow

\section{INTRODUCTION}

The dairy cow's transition from the dry period to lactation is characterized by changes in various hormones, challenges to homeostasis, and metabolic stress (Goff and Horst, 1997). Plasma NEFA are elevated when the cow mobilizes fatty acids from adipose tissue in response to the metabolic changes and negative energy balance, which is related to increased hepatic triglyceride (TG) accumulation and ketosis (Grummer, 1993; Drackley, 1999).

The increase in oxygen requirements with increased metabolic demands during the transition period results in augmented production of reactive oxygen species. The level of free radicals can exceed the endogenous antioxidant capacity of the animal, leading to oxidative stress (Miller and Brezeinska-Slebodizinska, 1993; Weiss, 1998). Oxidative stress is a significant underlying factor that can increase the susceptibility of dairy cattle, especially transition cows, to a variety of health disorders, including immunodeficiency, mastitis, and infertility (Allison and Laven, 2000; Castillo et al., 2005; Sordillo and Aitken, 2009). Therefore, failure to adequately control oxidative stress can result in an increased incidence of health disorders.

Niacin (nicotinic acid) is a precursor of the coenzyme NAD-NADP, which participates in anabolic and catabolic pathways. Recent research (Pires and Grummer, 2007) in the bovine has shown that niacin is a powerful antilipolytic agent that decreases the elevation of NEFA under negative energy balance (NEB) conditions. Emerging research (Varella Morandi Junqueira-Franco et al., 2006; Kamanna and Kashyap, 2007) suggests a novel mechanistic function for niacin in decreasing oxidative stress and metabolic diseases beyond its conventional role as a vitamin. Furthermore, niacin supplementation may provide potential beneficial effects in 
cows exposed to heat stress (Di Constanzo et al., 1997). However, supplemental niacin is extensively degraded in the rumen, and rumen absorption of niacin appears to be insignificant (Erickson et al., 1991; Campbell et al., 1994). With advances in vitamin encapsulation technology, NiaShure was developed to protect niacin from rumen degradation (Balchem Corp., New Hampton, NY), allowing a more effective option for dietary supplementation. By feeding this product, Zimbelman et al. (2010) reported increased free plasma niacin concentrations in dairy cows, indicating ruminal bypass and intestinal bioavailability of niacin. The objective of this experiment was to evaluate the effect of NiaShure on lipid metabolism, oxidative stress, and performance of transition dairy cows.

\section{MATERIALS AND METHODS}

The trial was conducted from June through September 2010 at the University of Wisconsin-Madison Dairy Cattle Center (Madison). The Institutional Animal Care and Use Committee of the College of Agriculture and Life Sciences at the University of WisconsinMadison approved the experimental protocol. Thirty nonlactating multiparous Holstein cows in late gestation were paired according to expected calving date and randomly assigned to either the rumen-protected niacin (RPN) product or an unsupplemented control (CON) TMR from $21 \mathrm{~d}$ before anticipated calving date through $21 \mathrm{~d}$ after parturition. Body weight and BCS were not different $(P>0.10)$ between treatment groups at the beginning of the study. Cows were housed in tie-stalls bedded with sawdust and milked in a parlor.

Pre- and postpartum diets were formulated to meet or exceed NRC (2001) requirements for CP, NDF, macrominerals, trace minerals, and vitamins $\mathrm{A}$ and D. Vitamin E supplementation was lower than NRC (2001) requirements for all experimental cows (prepartum: $482 \mathrm{IU} /$ cow per day provided vs. 1,211 IU/cow per day required; postpartum: $344 \mathrm{IU} /$ cow per day provided vs. $545 \mathrm{IU} /$ cow per day required) in an attempt to minimize the antioxidant effect of vitamin E (NRC, 2001) when evaluating the effect of niacin on oxidative stress. The CON or RPN premixes were added to TMR at the rate of $57 \mathrm{~g} / \mathrm{cow}$ per day to provide a daily supplemental RPN product intake of 0 or $12 \mathrm{~g} /$ cow per day. Because the RPN product contains $65 \%$ niacin, the actual niacin supplementation for treatment cows was about $8 \mathrm{~g} / \mathrm{cow}$ per day. The premixes were prepared by Vita Plus Corp. (Madison, WI) using a wheat red dog (Blasi et al., 1998) carrier. The CON and RPN TMR were mixed and fed daily at $0900 \mathrm{~h}$ for ad libitum consumption by targeting a $10 \%$ daily feed refusal for each cow from $21 \mathrm{~d}$ before expected calving date to $21 \mathrm{~d}$ postpartum. Individual cow TMR amounts fed and refused were measured daily. The DM contents of alfalfa silage and corn silage were determined weekly using a $60^{\circ} \mathrm{C}$ forced-air oven to adjust the as-fed ratios of diet ingredients in the TMR. Alfalfa silage, corn silage, wheat straw, dry and lactating cow concentrate mixes, and dry and lactating cow CON and RPN TMR samples were obtained weekly. Samples were dried for $48 \mathrm{~h}$ in a $60^{\circ} \mathrm{C}$ forced-air oven to determine DMI and ground to pass a 1-mm Wiley mill screen (Arthur H. Thomas, Swedesboro, NJ). Each type of weekly ground sample was composited by month to create 3 lactating cow and 4 dry cow samples for nutrient analysis. Samples were analyzed for DM, OM (method 942.05; AOAC, 2006), CP (method 990.03; AOAC, 2006), NDF (using $\alpha$-amylase and sodium sulfite; Van Soest et al., 1991), starch (Bach Knudsen, 1997), and ether extract (method 2003.05; AOAC, 2006) by Dairyland Laboratories Inc. (Arcadia, WI).

Cows were milked twice daily at 0400 and $1600 \mathrm{~h}$, and production was recorded at each milking during the trial. After each milking, cows were allowed to exercise for approximately $2 \mathrm{~h}$. Milk samples collected at 4 consecutive a.m. and p.m. milkings each week were analyzed for fat, true protein, lactose, MUN, and somatic cells by infrared analysis (Ag Source Milk Analysis Laboratory, Menomonie, WI) using a Foss FT6000 (Foss Electric, Hillerød, Denmark). Yields of 3.5\% FCM and ECM were calculated according to NRC (2001) equations.

Body weight and BCS ( 1 to 5 in 0.25-unit increments; Wildman et al., 1982) were recorded once weekly on Thursday at $1300 \mathrm{~h}$. Incidences of health disorders during the experimental period were recorded. Urine ketones were measured once daily for all cows from $d$ 1 to 21 relative to calving. Subclinical ketosis was recorded when the cow's urine ketone dipstick (Ketostix, Bayer Corp. Diagnostics Division, Elkhart, IN) test was categorized as small, moderate, or large, but not negative or trace. Three cows were excluded from the trial. One RPN cow developed toxic mastitis and the other 2 cows ( $1 \mathrm{CON}$ and $1 \mathrm{RPN}$ ) were diagnosed with leg nerve injuries. These cows were not replaced and no data from these cows were used.

Blood samples were taken at $0700 \mathrm{~h}$ via puncture of the coccygeal vein or artery on $\mathrm{d}-21,-14,-7,1,7$, 14, and 21 relative to calving. Approximately $12 \mathrm{~mL}$ of blood was drawn into 2 Vacutainers (Becton Dickinson, Franklin Lakes, NJ), one containing potassium EDTA [for superoxide dismutase (SOD) analysis] and the other containing potassium oxalate with sodium fluoride as a glycolytic inhibitor (for glucose, NEFA, and BHBA analyses), and both tubes were kept on ice. After centrifugation of blood samples at 2,000 $\times g$ for 15 min at $4^{\circ} \mathrm{C}$, plasma was obtained, and aliquots then 
were kept at $-20^{\circ} \mathrm{C}$ (for NEFA, BHBA, and glucose analyses) or $-80^{\circ} \mathrm{C}$ (for SOD analysis) until laboratory analyses were performed. Plasma samples were analyzed for NEFA (samples on $\mathrm{d}-21,1,7,14$, and 21 relative to calving; acetyl-CoA synthase, acyl-CoA oxidase and peroxidase, HR Series NEFA-2; Wako Pure Chemical Industries Ltd. USA, Richmond, VA), BHBA (samples on d 1, 7, 14, and 21 relative to calving; Gibbard and Watkins, 1968), glucose (samples on d -21, 1, 7, 14, and 21 relative to calving; glucose oxidase-peroxidase method; Karkalas, 1985), and SOD (samples on d -21 , $-14,-7,1,7,14$, and 21 relative to calving; SOD Assay Kit \#706002, Cayman Chemical Company, Ann Arbor, MI).

On d 1 and 21 postpartum, liver samples were taken by puncture biopsy after preparation of an aseptic area and administration of a local anesthetic $(10 \mathrm{~mL}$ of lidocaine). Liver samples were rinsed in saline, frozen in liquid nitrogen, and then stored at $-80^{\circ} \mathrm{C}$ until determination of TG concentration. Samples were thawed on ice and blotted dry, and approximately $0.1 \mathrm{~g}$ of tissue was homogenized in $3 \mathrm{~mL}$ of saline:methanol (1:1). An aliquot was used for total lipid extraction by the method of Folch et al. (1957). Concentration of TG was determined using a colorimetric assay (Foster and Dunn, 1973), and a second aliquot of the homogenate was used to measure DNA content of the sample (Labarca and Paigen, 1980).

Energy balance (EB) was calculated both pre- and postpartum for each cow using the following equations from NRC (2001). Prepartum energy balance $=$ net energy of intake - (net energy of maintenance + net energy of pregnancy). Net energy intake was calculated by multiplying DMI by the calculated net energy value of the diet; net energy of maintenance $=0.08 \times \mathrm{BW}^{0.75}$; and net energy of pregnancy $=[(0.00318 \times$ days pregnant -0.0352$) \times($ calf $\mathrm{BW} / 45)] / 0.218$. An average calf weight of $45 \mathrm{~kg}$ and days pregnant of $250 \mathrm{~d}$ were used to calculate net energy of pregnancy. Postpartum energy balance $=$ net energy of intake - (net energy of maintenance + net energy of lactation). Net energy of lactation $=[(0.0929 \times$ fat $\%)+(0.0547 \times$ protein $\%)$ $+(0.0395 \times$ lactose $\%)] \times$ milk production.

Data were analyzed for a completely randomized block design using Proc Mixed (SAS Institute, 2004) with repeated measures. Week or day was used as repeated measures using the first-order autoregressive covariance structure that provided the best fit according to Sawa's Bayesian information criterion. The model included block, treatment, time, and 2- and 3-way interactions as fixed effects, and cow nested within treatment and block as random effects. Degrees of freedom were calculated using the Kenward-Roger option. Means were determined using the least squares means statement, and treatment means were compared using the PDIFF option. Significance was declared at $P \leq$ 0.05 and trends at $P \geq 0.06$ and $<0.10$.

\section{RESULTS AND DISCUSSION}

\section{Diet Composition and DMI}

The ingredient and nutrient composition of the diets is presented in Table 1. Least squares means for average DMI are presented in Table 2 . A time effect $(P<0.01)$ was observed, with both groups experiencing a decrease in DMI from $\mathrm{d}-21$ to 0 and an increase from $\mathrm{d} 1$ to 21 relative to calving; however, no CON versus RPN treatment differences $(P>0.10)$ were observed. The intake depression around calving can lead to NEB and promote fat mobilization from adipose tissue (Doepel et al., 2002). Interestingly, in a recent transition cow study in which $24 \mathrm{~g} / \mathrm{d}$ of an RPN product was fed, Morey et al. (2011) reported a decrease in DMI for RPN-treated cows by $4 \mathrm{~kg} / \mathrm{d}$ compared with control cows during the final $4 \mathrm{~d}$ prepartum. In our study, however, no differences $(P>0.10)$ in DMI were found between treatments.

\section{Milk Production, BW, BCS, and EB}

Least squares means for milk yield, milk composition, and component yields of cows fed diets with and without addition of RPN are presented in Table 2. Milk yield, milk protein percentage, milk protein yield, and milk fat yield were unaffected $(P>0.10)$ by treatment. Under heat-stress conditions, Di Costanzo et al. (1997) reported that supplemental dietary rumen-unprotected niacin (12, 24, or $36 \mathrm{~g} / \mathrm{cow}$ per day) did not affect milk yield, FCM yield, or milk composition of lactating cows, whereas Muller et al. (1986) reported that feeding $6 \mathrm{~g} / \mathrm{d}$ of rumen-unprotected niacin increased milk by $1 \mathrm{~kg} / \mathrm{d}$ on average, and cows producing $>34 \mathrm{~kg} / \mathrm{d}$ responded by $2.4 \mathrm{~kg} / \mathrm{d}$ in the summer in Pennsylvania. A recent research trial (Yuan et al., 2011) from our laboratory conducted in the summer in Wisconsin reported that supplementation with $12 \mathrm{~g} / \mathrm{d}$ of an RPN product did not improve milk yield or composition in mid-lactation dairy cows. The reasons for the inconsistent production responses to niacin supplementation among trials are not clear. Interestingly, as shown in Figure 1, cows fed RPN had lower $(P<0.05)$ ECM yield $(28.7$ vs. 37.2 $\mathrm{kg} / \mathrm{d}$ ) in the first week of lactation. First-week $3.5 \%$ FCM yield (28.0 vs. $36.9 \mathrm{~kg} / \mathrm{d})$ was also reduced $(P$ $<0.05)$ by RPN. The lower ECM and $3.5 \%$ FCM in early lactation in RPN cows may be associated with reduced plasma NEFA concentrations around calving, as NEFA can be transferred to milk fat by the mammary 
Table 1. Diet ingredient and nutrient composition

\begin{tabular}{lcc}
\hline Item & $\begin{array}{c}\text { Prepartum } \\
\text { diet }\end{array}$ & $\begin{array}{c}\text { Postpartum } \\
\text { diet }\end{array}$ \\
\hline Ingredient, \% of DM & 54.8 & 26.5 \\
Corn silage & - & 26.5 \\
Alfalfa silage & 23.5 & 2.2 \\
Wheat straw & - & 22.1 \\
Dry ground shelled corn & 17.8 & 4.9 \\
Soybean meal, 48\%, solvent & - & 13.1 \\
Soybean meal, expeller & - & 0.9 \\
Sodium bicarbonate & 1.0 & 0.8 \\
Calcium carbonate & 0.8 & - \\
Calcium sulfate & 0.4 & - \\
Magnesium sulfate & 0.4 & 0.5 \\
Trace mineral salt & \\
Urea & 0.4 & 0.3 \\
Magnesium oxide & - & 0.1 \\
Mg-K-S & 0.2 & 1.7 \\
Animal fat & 0.4 & 0.2 \\
Vitamin ADE premix ${ }^{3}$ & 0.3 & 0.2 \\
Monocalcium phosphate & & \\
Nutrient, \% of DM & 49.7 & 50.1 \\
DM, \% of as-fed & 14.1 & 16.9 \\
CP & 44.1 & 27.7 \\
NDF & 42.6 & 23.0 \\
NDF from forage & 18.3 & 24.2 \\
Starch & 2.6 & 5.6 \\
Ether extract & 8.0 & 8.0 \\
Ash & &
\end{tabular}

${ }^{1} 88 \% \mathrm{NaCl} ; 0.004 \% \mathrm{Co} ; 0.325 \% \mathrm{Cu} ; 0.0175 \%$ I; $0.02 \%$ Fe; $1.0 \% \mathrm{Mn}$; $0.0065 \%$ Se; $1.4 \% \mathrm{Zn}$

${ }^{2}$ Dynamate $(11 \% \mathrm{Mg}, 18 \% \mathrm{~K}, 22 \% \mathrm{~S}$; The Mosaic Co., Plymouth, MN).

${ }^{3}$ Vitamin A, 3,300,000 IU/kg; vitamin D, 1,100,000 IU/kg; vitamin E, $11,000 \mathrm{IU} / \mathrm{kg}$. gland. In fact, milk fat percentage (4.44 vs. $5.08 \%)$ was reduced $(P=0.05)$ by $\mathrm{RPN}$, and we observed a tendency for a treatment $\times$ time interaction $(P<0.10)$ for milk fat yield. These data support the concept that niacin can block fatty acid mobilization and therefore reduce milk energy output postpartum. Based on the interaction shown in Figure 1, we may have observed a more positive response for RPN cows if ECM had been measured later in lactation. Somatic cell score was lower $(P<0.05)$ for RPN than CON (2.48 vs. 3.93). Somatic cell score has long been used to indicate the severity of inflammation of the mammary gland and mastitis in dairy cows. Recently, Suriyasathaporn et al. (2006) reported that SCS was also positively related $(P<0.01)$ to lipid peroxidation in raw milk, suggesting a relationship between SCS and oxidative stress. A reduced SCS for RPN-treated cows may indicate attenuated oxidative stress and inflammation in early lactation cows.

Least squares means for BW, BCS, and EB are presented in Table 2. Body weight and BCS decreased $(P<0.01)$ during the experiment, but no differences $(P>0.10)$ were observed between treatments. Prepartum EB was unaffected $(P>0.10)$ by treatment. A tendency $(P<0.10)$ was observed for treatment and treatment $\times$ time effects for EB postpartum. The more positive postpartum energy status in RPN-treated cows $(-8.4$ vs. $-11.9 \mathrm{Mcal} / \mathrm{d})$ is related to their reduced milk energy output and adipose mobilization, which might contribute to a reduced risk of metabolic disorders (Drackley, 1999; Odens et al., 2007).

Table 2. Least squares means for milk yield, milk composition, and component yields, DMI, BW, BCS, and energy balance (EB) of cows fed diets with and without addition of rumen-protected niacin (RPN)

\begin{tabular}{|c|c|c|c|c|c|c|}
\hline \multirow[b]{2}{*}{ Item } & \multicolumn{2}{|c|}{$\mathrm{RPN}, \mathrm{g} / \mathrm{d}$} & \multirow[b]{2}{*}{ SEM } & \multicolumn{3}{|c|}{$P$-value } \\
\hline & 0 & 12 & & $\mathrm{RPN}$ & Wk & $\mathrm{RPN} \times \mathrm{Wk}$ \\
\hline Prepartum DMI, kg/d & 10.2 & 11.7 & 0.7 & 0.14 & 0.02 & 0.81 \\
\hline Postpartum DMI, $\mathrm{kg} / \mathrm{d}$ & 15.5 & 15.9 & 0.9 & 0.80 & $<0.001$ & 0.65 \\
\hline Milk, $\mathrm{kg} / \mathrm{d}$ & 32.8 & 33.3 & 1.8 & 0.81 & $<0.001$ & 0.59 \\
\hline $\mathrm{ECM}^{1}{ }^{1} \mathrm{~kg} / \mathrm{d}$ & 40.3 & 37.1 & 2.2 & 0.29 & $<0.001$ & 0.04 \\
\hline $3.5 \% \mathrm{FCM}^{2}{ }^{2} \mathrm{~kg} / \mathrm{d}$ & 41.2 & 37.9 & 2.3 & 0.29 & $<0.001$ & 0.05 \\
\hline Fat, $\%$ & 5.08 & 4.44 & 0.22 & 0.05 & 0.12 & 0.15 \\
\hline Fat, $\mathrm{kg} / \mathrm{d}$ & 1.66 & 1.46 & 0.10 & 0.18 & $<0.001$ & 0.06 \\
\hline Protein, \% & 3.44 & 3.21 & 0.10 & 0.15 & $<0.001$ & 0.38 \\
\hline Protein, kg/d & 1.11 & 1.04 & 0.07 & 0.41 & 0.11 & 0.11 \\
\hline Lactose, $\%$ & 4.56 & 4.70 & 0.06 & 0.15 & $<0.001$ & 0.11 \\
\hline $\mathrm{SCS}^{3}$ & 3.93 & 2.48 & 0.43 & 0.03 & $<0.001$ & 0.17 \\
\hline MUN, mg/dL & 11.9 & 13.4 & 0.8 & 0.20 & 0.52 & 0.70 \\
\hline $\mathrm{BW}, \mathrm{kg}$ & 731 & 732 & 21 & 0.98 & $<0.0001$ & 0.34 \\
\hline BCS & 3.19 & 3.11 & 0.15 & 0.71 & $<0.0001$ & 0.59 \\
\hline Prepartum EB, Mcal/d & -1.24 & 0.70 & 0.91 & 0.14 & 0.01 & 0.90 \\
\hline Postpartum EB, Mcal/d & -11.9 & -8.4 & 1.51 & 0.09 & 0.07 & 0.10 \\
\hline
\end{tabular}

${ }^{1}$ Calculated according to NRC (2001) equations.

${ }^{2}$ Fat-corrected milk calculated according to NRC (2001) equations.

${ }^{3} \mathrm{SCS}=\log _{2}(\mathrm{SCC} / 100)+3 ;($ Shook, 1993). 


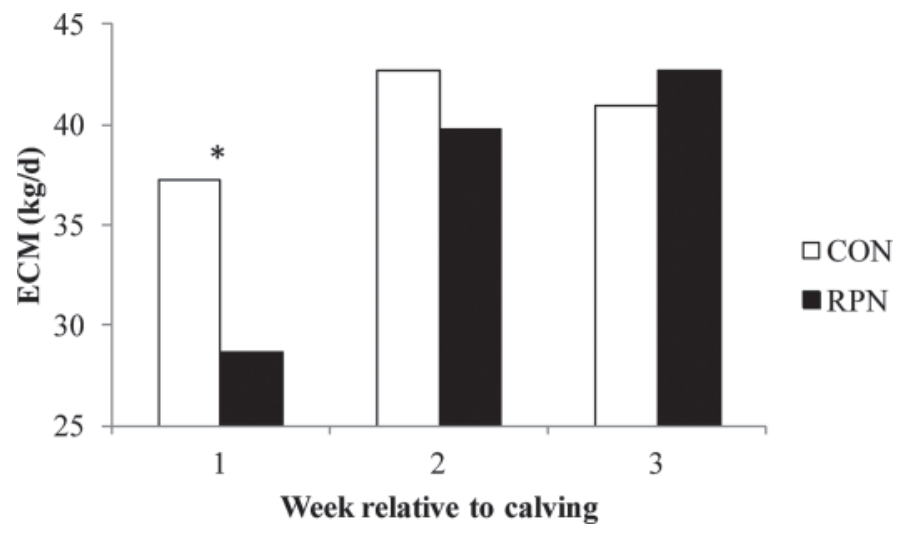

Figure 1. Energy-corrected milk yield of cows fed diets without $(\mathrm{CON})$ and with addition of rumen-protected niacin (RPN) during the experimental period. ${ }^{*}$ Indicates difference $(P<0.05)$ between treatments. Time $(P<0.01)$ and treatment $\times$ time interaction $(P<0.05)$; $\mathrm{SEM}=2.2 \mathrm{~kg} / \mathrm{d}$.

\section{Plasma NEFA}

Results for plasma NEFA concentration on d $-21,1$, 7,14 , and 21 relative to calving are presented in Figure 2. Compared with 21 d prepartum, plasma NEFA concentrations increased at calving and gradually declined after parturition to d 21 postpartum in both treatment groups. On the day after calving, NEFA reached 1,138 $\pm 80 \mu \mathrm{Eq} / \mathrm{L}$ for $\mathrm{CON}$ cows compared with $698 \pm 80$ $\mu \mathrm{Eq} / \mathrm{L}$ for RPN cows and differed $(P<0.01)$ by treatment. Cows fed RPN tended $(P<0.10)$ to have lower plasma NEFA concentrations than control cows on $\mathrm{d}$ 7 and 14 postpartum. Time $(P<0.01)$ and treatment $\times$ time $(P<0.05)$ effects over the experiment were observed. An effect of niacin is to inhibit lipolysis in adipose tissue leading to a lowering of plasma NEFA (Carlson, 2005). Our results suggest that niacin inhibited lipolysis in cows around calving. Waterman et al. (1972) reported that pharmacological doses of niacin given over $8 \mathrm{~h}$ decreased plasma NEFA in ketotic dairy cows. However, with supplementation of 6 to $12 \mathrm{~g} / \mathrm{d}$ of dietary rumen-unprotected niacin, plasma NEFA concentrations were reduced in only 1 of 11 transition-cow experiments (NRC, 2001). Recently, Pires and Grummer (2007) reported that niacin infused postruminally into the abomasum is a powerful antilipolytic agent in bovines in NEB due to feed restriction. Because supplemental niacin is extensively degraded in the rumen and ruminal absorption is minimal (Erickson et al., 1991; Campbell et al., 1994), RPN should be a more effective option than unprotected niacin for dietary supplementation. By feeding $24 \mathrm{~g} / \mathrm{d}$ of RPN product, Morey et al. (2011) observed suppression of NEFA in cows close to calving. Herein, we observed that a dosage of RPN product as low as $12 \mathrm{~g} / \mathrm{d}$ reduced NEFA concentra- tions. The results support that this RPN product effectively escaped ruminal degradation and was intestinally bioavailable.

\section{Plasma Glucose, BHBA, and SOD and Liver TG}

Results for plasma glucose, BHBA, and SOD and liver TG are presented in Table 3 . No treatment $(P$ $>0.10)$ or treatment $\times$ time $(P>0.10)$ effects were observed. Similar to our findings, previous studies reported no effects of either unprotected (Belibasakis and Tsirgogianni, 1996; Madison-Anderson et al., 1997) or protected (Morey et al., 2011) niacin on blood glucose. Although no treatment effects $(P>0.10)$ were observed for BHBA, feeding $12 \mathrm{~g} /$ cow of rumen-unprotected niacin per day has been shown to reduce BHBA in postpartum cows (Erickson et al., 1992). Liver TG concentrations were numerically lower for RPN than for CON cows at both $d 1$ and d 21 postpartum. Because hepatic TG accumulation is directly related to blood NEFA concentration (Emery et al., 1992), reduced postpartum NEFA concentrations for RPN (compared with CON) may lead to less TG accumulation.

Superoxide dismutase is an important intracellular antioxidant that is considered to be the first defense against preoxidants that convert the superoxide to hydrogen peroxide (Halliwell and Chirico, 1993), and it can be induced to protect against prooxidant insults resulting from cytokine treatment, irradiation, and certain tumors (Macmillan-Crow and Cruthirds, 2001). Bernabucci et al. (2002) reported that cows showed increased SOD around calving, and this increase may

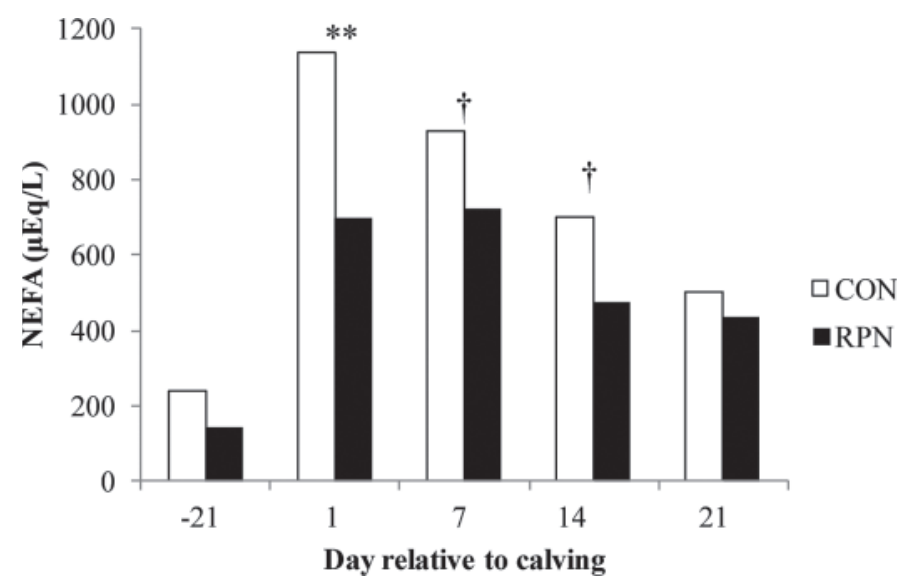

Figure 2. Plasma NEFA concentration of cows fed diets without $(\mathrm{CON})$ and with addition of rumen-protected niacin (RPN) during the experimental period. **Indicates difference $(P<0.01)$ between treatments; †indicates a tendency for a treatment effect $(P<0.10)$. Time $(P<0.01)$ and treatment $\times$ time interaction $(P<0.05)$; SEM $=113 \mu \mathrm{Eq} / \mathrm{L}$. 
Table 3. Least squares means for plasma glucose, BHBA, superoxide dismutase (SOD), and liver triglyceride (TG) concentrations of cows fed diets with and without addition of rumen-protected niacin $(\mathrm{RPN})^{1}$

\begin{tabular}{|c|c|c|c|}
\hline \multirow[b]{2}{*}{ Item } & \multicolumn{2}{|c|}{$\mathrm{RPN}, \mathrm{g} / \mathrm{d}$} & \multirow[b]{2}{*}{ SEM } \\
\hline & 0 & 12 & \\
\hline \multicolumn{4}{|c|}{ Glucose, $\mathrm{mg} / \mathrm{dL}$} \\
\hline $\mathrm{d}-21$ & 66.7 & 68.9 & 3.0 \\
\hline d 1 & 62.5 & 66.2 & 2.9 \\
\hline d 7 & 54.7 & 59.9 & 2.9 \\
\hline d 14 & 57.4 & 60.7 & 3.0 \\
\hline d 21 & 61.8 & 63.5 & 2.9 \\
\hline \multicolumn{4}{|c|}{ BHBA, mg/dL } \\
\hline $\mathrm{d} 1$ & 9.1 & 7.3 & 2.7 \\
\hline d 7 & 18.5 & 16.2 & 2.7 \\
\hline d 14 & 17.9 & 12.1 & 2.7 \\
\hline d 21 & 18.1 & 10.4 & 2.7 \\
\hline \multicolumn{4}{|c|}{$\mathrm{SOD}, \mathrm{U}^{2} / \mathrm{mL}$} \\
\hline $\mathrm{d}-21$ & 3.23 & 3.50 & 0.22 \\
\hline $\mathrm{d}-14$ & 4.05 & 3.79 & 0.23 \\
\hline $\mathrm{d}-7$ & 3.48 & 3.73 & 0.24 \\
\hline d 1 & 3.92 & 3.79 & 0.23 \\
\hline d 7 & 3.92 & 3.72 & 0.23 \\
\hline d 14 & 4.17 & 3.57 & 0.23 \\
\hline d 21 & 3.94 & 3.89 & 0.23 \\
\hline \multicolumn{4}{|c|}{$\mathrm{TG}, \mu \mathrm{g} / \mu \mathrm{g}$ of DNA } \\
\hline d 1 & 8.77 & 5.05 & 2.48 \\
\hline d 21 & 13.25 & 6.31 & 2.54 \\
\hline
\end{tabular}

${ }^{1}$ No treatment $\times$ time interactions $(P>0.10)$.

${ }^{2}$ One unit $(\mathrm{U})$ is defined as the amount of enzyme needed to exhibit $50 \%$ dismutation of the superoxide radical.

represent compensatory changes that the cow undergoes in response to increased oxidative stress, which may be exacerbated by parturition. Although SOD was unaffected $(P>0.10)$ by treatment in the present study, we speculate that niacin may have antioxidant potential via inhibiting lipolysis, thereby decreasing the amount of fatty acid substrates available for lipid peroxidation. It should be noted that SOD is only one of the many enzymes involved in oxidative stress and it may not accurately represent the complex oxidative stress profile. More bovine-specific oxidative stress markers need to be assessed to test the effects of RPN on the oxidative status of transition dairy cows.

\section{Incidence of Health Disorders}

The incidences of subclinical ketosis were $43 \%$ (6 of 14 cows) and $31 \%$ (4 of 13 cows) for CON and RPN, respectively, which were higher than the average prevalence $(\sim 15 \%)$ in the United States (Oetzel, 2007). Nevertheless, prevalence as high as $34 \%$ has been observed (Kauppinen, 1983), and Morey et al. (2011) recently reported a $45.5 \%$ ketosis rate in either control or supplemented ( $24 \mathrm{~g} / \mathrm{d}$ of RPN product) groups. Because the small number of cows in the present study did not provide enough statistical power, we did not test for differences in the incidence of health disorders between treatments. One cow in the RPN group developed displaced abomasum, and 2 cows in each treatment group presented with retained placenta.

\section{CONCLUSIONS}

Dietary supplementation with $12 \mathrm{~g} /$ cow per day of RPN product inhibited lipolysis, reduced milk energy output, and improved postpartum energy balance, but did not affect the antioxidant enzyme SOD or feed intake of transition dairy cows. The RPN product used in this study escaped ruminal degradation and provided an intestinally bioavailable niacin source for transition dairy cows. Dietary supplementation with RPN may have the potential to reduce the risk of metabolic disorders in transition dairy cows and further research is warranted.

\section{ACKNOWLEDGMENTS}

The authors thank Balchem Corp. (New Hampton, NY) for donating Niashure and providing partial financial support for this research trial. Appreciation is extended to Peter Crump (University of Wisconsin-Madison, College of Agriculture and Life Sciences Statistical Consulting Service) for statistical advice; the staff at University of Wisconsin-Madison Dairy Cattle Center for animal care and trial management; Teresa Kaiser, Luiz Ferraretto, and other students in the University of Wisconsin-Madison Dairy Nutrition Laboratory for data collection; and Vita Plus Corp. (Madison, WI) for premix formulation and preparation.

\section{REFERENCES}

Allison, R. D., and R. A. Laven. 2000. Effect of vitamin E supplementation on the health and fertility of dairy cows: A review. Vet. Rec. 147:703-708.

AOAC. 2006. 18th ed. Official Methods of Analysis. Assoc. Off. Anal. Chem., Arlington, VA.

Bach Knudsen, K. E. 1997. Carbohydrate and lignin contents of plant materials used in animal feeding. Anim. Feed Sci. Technol. 67:319-338.

Belibasakis, N. G., and D. Tsirgogianni. 1996. Effects of niacin on milk yield, milk composition, and blood components of dairy cows in hot weather. Anim. Feed Sci. Technol. 64:53-59.

Bernabucci, U., B. Ronchi, N. Lacetera, and A. Nardone. 2002. Markers of oxidative status in plasma and erythrocytes of transition dairy cows during hot season. J. Dairy Sci. 85:2173-2179.

Blasi, D. A., G. L. Kuhl, J. S. Drouillard, C. L. Reed, D. M. TrigoStockli, K. C. Behnke, and F. J. Fairchild. 1998. Wheat middlings composition, feed value, and storage guidelines. MF-2353. Kansas State Univ. Agric. Exp. Stn. Coop. Ext. Serv., Manhattan. Accessed Dec. 14, 2011. http://www.ksre.ksu.edu/library/lvstk2/ mf2353.pdf.

Campbell, J. M., M. R. Murphy, R. A. Christensen, and T. R. Overton. 1994. Kinetics of niacin supplements in lactating dairy cows. J. Dairy Sci. 77:566-575.

Carlson, L. A. 2005. Nicotinic acid: The broad-spectrum lipid drug. A 50th anniversary review. J. Intern. Med. 258:94-114. 
Castillo, C., J. Hernandez, A. Bravo, M. Lopez-Alonso, V. Pereira, and J. L. Benedito. 2005. Oxidative status during late pregnancy and early lactation in dairy cows. Vet. J. 169:286-292.

Di Costanzo, A., J. N. Spain, and D. E. Spiers. 1997. Supplementation of nicotinic acid for lactating Holstein cows under heat stress conditions. J. Dairy Sci. 80:1200-1206.

Doepel, L., H. Lapierre, and J. J. Kennelly. 2002. Peripartum performance and metabolism of dairy cows in response to prepartum energy and protein intake. J. Dairy Sci. 85:2315-2334.

Drackley, J. K. 1999. Biology of dairy cows during the transition period: The final frontier? J. Dairy Sci. 82:2259-2273.

Emery, R. S., J. S. Liesman, and T. H. Herdt. 1992. Metabolism of long-chain fatty acids by ruminant liver. J. Nutr. 122:832-837.

Erickson, P. S., M. R. Murphy, and J. H. Clark. 1992. Supplementation of dairy cow diets and calcium salts of long-chain fatty acids and nicotinic acid in early lactation. J. Dairy Sci. 75:1078-1089.

Erickson, P. S., M. R. Murphy, C. S. McSweeney, and A. M. Trusk. 1991. Niacin absorption from the rumen. J. Dairy Sci. 74:34923495.

Folch, J., M. Lees, and G. H. Sloane Stanley. 1957. A simple method for the isolation and purification of total lipids from animal tissues. J. Biol. Chem. 226:497-509.

Foster, L. B., and R. T. Dunn. 1973. Stable reagents for determination of serum triglycerides by a colorimetric Hantzsch condensation method. Clin. Chem. 19:338-340.

Gibbard, S., and P. J. Watkins. 1968. A micro-method for the enzymatic determination of D- $\beta$-hydroxybutyrate and acetoacetate. Clin. Chim. Acta 19:511-521.

Goff, J. P., and R. L. Horst. 1997. Physiological changes at parturition and their relationship to metabolic disorders. J. Dairy Sci. $80: 1260-1268$.

Grummer, R. R. 1993. Etiology of lipid-related metabolic disorders in periparturient dairy cows. J. Dairy Sci. 76:3882-3896.

Halliwell, B., and S. Chirico. 1993. Lipid peroxidation: Its mechanism, measurement, and significance. Am. J. Clin. Nutr. 57:715S-724S.

Kamanna, V. S., and M. L. Kashyap. 2007. Nicotinic acid (niacin) receptor agonists: Will they be useful therapeutic agents? Am. J. Cardiol. 100:S53-S61.

Karkalas, J. J. 1985. An improved enzymatic method for the determination of native and modified starch. J. Sci. Food Agric. 36:1019-1027.

Kauppinen, K. 1983. Prevalence of bovine ketosis in relation to number and stage of lactation. Acta Vet. Scand. 24:349-361.

Labarca, C., and K. Paigen. 1980. A simple, rapid, and sensitive DNA assay procedure. Anal. Biochem. 102:344-352.

Macmillan-Crow, L. A., and D. L. Cruthirds. 2001. Invited review: Manganese superoxide dismutase in disease. Free Radic. Res. 34:325-336.

Madison-Anderson, R. J., D. J. Schingoethe, M. J. Brouk, R. J. Baer, and M. R. Lentsch. 1997. Response of lactating cows to supplemental unsaturated fat and niacin. J. Dairy Sci. 80:1329-1338.

Miller, J. K., and E. Brezeinska-Slebodizinska. 1993. Oxidative stress, antioxidants and animal function. J. Dairy Sci. 76:2812-2823.

Morey, S. D., L. K. Mamedova, D. E. Anderson, C. K. Armendariz, E. C. Titgemeyer, and B. J. Bradford. 2011. Effects of encapsulated niacin on metabolism and production of periparturient dairy cows. J. Dairy Sci. 94:5090-5104.

Muller, L. D., A. J. Heinrichs, J. B. Cooper, and Y. H. Atkin. 1986. Supplemental niacin for lactating cows during summer feeding. J. Dairy Sci. 69:1416-1420.

NRC. 2001. Nutrient Requirements of Dairy Cattle. 7th rev. ed. Natl. Acad. Press, Washington, DC.

Odens, L. J., R. Burgos, M. Innocenti, M. J. VanBaale, and L. H. Baumgard. 2007. Effects of varying doses of supplemental conjugated linoleic acid on production and energetic variables during the transition period. J. Dairy Sci. 90:293-305.

Oetzel, G. R. 2007. Herd-level ketosis: Diagnosis and risk factors. Pages 67-91 in Proc. Am. Assoc. Bov. Pract., Vancouver, BC, Canada. Am. Assoc. Bovine Pract., Opelika, AL.

Pires, J. A. A., and R. R. Grummer. 2007. The use of nicotinic acid to induce sustained low plasma nonesterified fatty acids in feedrestricted Holstein cows. J. Dairy Sci. 90:3725-3732.

SAS Institute. 2004. SAS/STAT 9.1 User's Guide. Version 9.1 ed. SAS Institute Inc., Cary, NC.

Shook, G. E. 1993. Genetic improvement of mastitis through selection on somatic cell count. Vet. Clin. North Am. Food Anim. Pract. 9:563-581.

Sordillo, L. M., and S. L. Aitken. 2009. Impact of oxidative stress on the health and immune function of dairy cattle. Vet. Immunol Immunopathol. 128:104-109.

Suriyasathaporn, W., U. Vinitketkumnuen, T. Chewonarin, S. Boonyayatra, K. Kreausukon, and Y. H. Schukken. 2006. Higher somatic cell counts resulted in higher malondialdehyde concentrations in raw cows' milk. Int. Dairy J. 16:1088-1091.

Van Soest, P. J., J. B. Robertson, and B. A. Lewis. 1991. Methods for dietary fiber, neutral detergent fiber, and nonstarch polysaccharides in relation to animal nutrition. J. Dairy Sci. 74:3583-3597.

Varella Morandi Junqueira-Franco, M., T. L. Ernesto, C. P. Garcia, M. do Rosario Del Lama Unamuno, J. A. Afonso, and H. Vannucchi. 2006. Intestinal permeability and oxidative stress in patients with alcoholic pellagra. Clin. Nutr. 25:977-983.

Waterman, R., J. W. Schwalm, and L. H. Schultz. 1972. Nicotinic acid treatment of bovine ketosis. I. Effects on circulatory metabolites and interrelationships. J. Dairy Sci. 55:1447-1453.

Weiss, W. P. 1998. Requirements of fat-soluble vitamins for dairy cows: A review. J. Dairy Sci. 81:2493-2501.

Wildman, E. E., G. M. Jones, P. E. Wagner, R. L. Boman, H. F. Troutt, and T. N. Lesch. 1982. A dairy cow body condition scoring system and its relationship to selected production characteristics. J. Dairy Sci. 65:495-501.

Yuan, K., R. D. Shaver, M. Espineira, and S. J. Bertics. 2011. Effect of a rumen-protected niacin product on lactation performance by dairy cows during the summer in Wisconsin. Prof. Anim. Sci. 27:190-194.

Zimbelman, R. B., L. H. Baumgard, and R. J. Collier. 2010. Effects of rumen-protected niacin on evaporative heat loss and body temperature in moderately heat-stressed lactating Holstein cows. J. Dairy Sci. 93:2387-2394. 